\title{
Concept of Freedom in Management
}

\author{
Grudziński Adam $^{1} \&$ Sulich Adam ${ }^{2}$ \\ ${ }^{1}$ Faculty of Computer Science and Management, Wroclaw University of Science and Technology, \\ Wroclaw, Poland \\ ${ }^{2}$ Faculty of Management, Computer Science and Finance, Wroclaw University of Economics, Wrocław, \\ Poland \\ Correspondence: Sulich Adam, Wroclaw University of Economics, Poland. \\ Email: adam.sulich@ue.wroc.pl
}

Received: June 9, 2019

Accepted: August 20, 2019

Online Published: September 1, 2019

doi: 10.23918/ijsses.v6i1p134

\begin{abstract}
The article is a result of the literature review in terms of freedom in management concept. The term freedom has many interpretations, which depend on the context of its analysis. Freedom in management is related strongly to the responsibility concept. There are also other dimensions like opportunities or incendiaries but also related to personal and organisational conditions. Undoubtedly, freedom is a fundamental value, but not the only one. Freedom in management sciences is a complex and multidimensional concept. Admittedly, without freedom, it is impossible to achieve other values on which organisations are built. This theoretical discussion aims to explain the role of freedom in management in contemporary practices of organisations and value in their development.
\end{abstract}

Keywords: Authority, Leadership, Modern Management, Value

\section{Introduction}

Freedom is a very desired idea or value and also accepted as a fundamental human right in modern society. Moreover, it is also a required condition for success both in social and business life, no matter if public or private. The idea of freedom is a crucial factor when it comes to present capitalism (Dierksmeier, 2011). Freedom itself is valuable, but it can also be destructive if not balanced with responsibility and duties (Dierksmeier \& Pirson, 2010). Management is the responsibility for the performance of a group of people. Moreover, the management is the process of planning, organising, leading and controlling individuals' activities, focused on achieving an established set of goals. These functions are all connected with making decisions, which can be defined as a process of establishing organisational goals, finding the ways of achieving them and preparing all required resources. These are related then again with equality and democracy, which assure freedom.

The management is often a complicated process which involves different managerial roles, and among them, the leadership over a group of workers seems to be the most important for the organisation's structure stability (Organa, 2018). In the traditional concept of management, person-in-charge has power over people, which means, that everyone acts, as they are trained and follow established procedures (Karaferye \& Agaoglu, 2017). It is an approach, which gives more value to power-with people and democratisation processes. This concept is based on real authority and trust, which are a result of skills, not only the position. Therefore, in organizations we can distinguish two the most important types of authorities: formal and personal. Formal authority is the result of organizational structure. While source of personal authority 
is intelligence, knowledge and experience. This approach allows bringing new added value (Khall Khalid, 2019) and something that all involved in the organisation, or just related to it, are looking for - the freedom. However, managers meet their first boundaries in the management process. They are limited, firstly by time, which is crucial in business, taking into consideration economic situation, that can easily change and secondly, by available resources. Therefore, the second limitation is equipment, financial resources or labour - meaning employees and their expectations (Sulich \& Zema, 2017a). These are also some limits of freedom in management related to the law of the organisation and management within it. It is worth to mention that freedom ends where someone else freedom begins.

This article explores the role of freedom in management in contemporary practices of organisations and value in their development. First. The dimensions of freedom in management are explored. Then a definition of freedom in management is presented. Finally, the case study analysis provides examples of successful and unsuccessful companies in terms of freedom in management. Based on this descriptive qualitative method, conclusions were presented.

\section{Dimensions of Freedom in Management}

There are two main dimensions of freedom in management, among public and private organisations. In public organisations, it can be said that freedom in management is similar in its concept to A. Smith's concept of economy, with one significant difference. The famous 'invisible hand' of the market is replaced by a manager, who has power-with people (Gomme, 1874; Smith, 2011). This person task is to give employees a goal, which is their goal and which they want to accomplish. As a result, every ' $\operatorname{cog}$ in the machine' is at its best, pretty much like in the free market, where people left on their own, know better than planner how to get what they want, and are just more effective on they own. The role of a manager is to adjust goals to workers in a way that their task matters to them. According to this idea, the leader should be a person, who engage organisation members to individualism and creativity instead of controlling workers on every step and demanding from them machine-like work ethic, which strictly follows some pattern (Bogusz \& Ziemkiewicz, 2018; Organa, 2018).

According to McGregor, there are two types of employees: " $X$ " and " $Y$ ". In approach " $X$ ", the managers assume that employees are lazy by nature and that they avoid work whenever possible. For this reason, employees must be strictly controlled. What is more you also need a hierarchical structure and meticulous control at every level. Furthermore, employees are deprived of ambition and show low initiative, they will strive to avoid responsibility as often as possible. On the other hand, approach "Y" assumes that people are always willing and creative; therefore, for them should be left an area of freedom to act, thanks to which they will achieve greater efficiency than if they are limited by procedures and the rule. Such employees should be assigned only directions of action in which they themselves find solutions. However, there is also the so-called theory "Self-fulfilling prophecy", which says that people are "X" or "Y" depending on how their manager treats. Figure 1 shows area of freedom for employees. An important element in the area of freedom is a specific barrier which is defined by organizational values. 


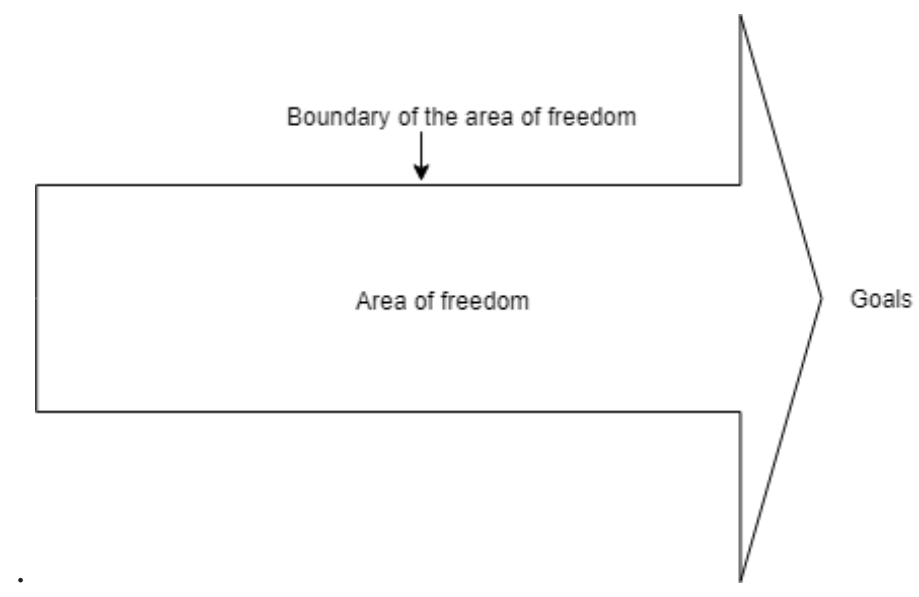

Figure 1: Area of freedom Source: own elaboration

Every business environment is going to require managers, and with that position will inevitably come power, authority, and autonomy. In certain instances, granting more autonomy to the manager may yield more creative solutions, while limiting his autonomy may yield more effective results. It is not hard to conclude that a management position overseeing a very systematic occupation such as manufacturing will not require more freedom for the manager. On the other hand, this does not work in every possible scenario. Sometimes a dilemma does not always have an obvious answer; that is why a manager must be granted some amount of freedom in order to execute the mission and achieve his firm's goals properly.

\section{Freedom in Management Definition}

There is no one, and generally accepted definition of the freedom in management as the term "freedom" by its' nature can be interpreted in multiple ways depending on the area of research, personal preferences, organisation's specifics. (Ivancevich \& Matteson, 1996). Some of the researches prefer not to use this term yet as this management practice (Chmielewska-Muciek, 2018; Sulich \& Zema, 2017b) is still on the evolving stage (Solari, 2016), this is not mature enough to have clear burdens for the notion establishment. Nonetheless, freedom in management might encompass the following features (Nobless \& Staley, 2009):

1. open-minded leadership,

2. self-direction,

3. self-control,

4. creative entrepreneurship,

5. self-motivation,

6. the balance between employee's and business' needs,

7. authority for daily tasks without the manager's approval,

8. people are less risk-averse.

Freedom in management is an opportunity to make management decisions independently, using the resources needed for the solution, and act on personal thinking about specific organisational activities within the organisational culture. This definition includes specific characteristics of managerial freedom and the moving process for each of the elements included therein may apply. There are four main elements: 
managerial decisions, resources needed for goals realisation, communication system and self-realisation (Tikhonova \& Zaytseva, 2015). Therefore, the possible advantages of managerial freedom are:

1. decision-making process takes less time, because the manager does not need to wait for decision approval, and, as a result, assigned tasks could be performed in a shorter period;

2. free access to resources needed to reach goals also gives the possibility to reduce time in tasks performance;

3. opportunity for manager development may reveal more valuable employee whose implemented decisions brings company benefit;

4. well-chosen type of communication will allow the manager, as well as ordinary employees, to perform work more efficiently;

5. for large corporations, it is an opportunity to streamline and speed up the implementation of daily and straightforward tasks, since there will be no need to coordinate each daily,

The disadvantages or challenges which can appear with managerial freedom are:

1. a critical condition for the existence of managerial freedom are well-established communication channels and, in case of issues related to the chosen type of communication and its structure, the company will lack manager who will summarise and accumulate the incoming heterogeneous information and take on its basis a comprehensive analysis of management decisions;

2. misunderstanding of the company's organisational activities within the organisational culture that will lead to inappropriate manager's decisions and cause the company's losses or a slowdown in goal achievement;

3. an incompetent manager who is not able to optimally use the company's resources, which will subsequently lead to a waste of resources and losses for the company;

4. one right independently-made decision could be a lucky strike, but the manager inspired by previous experience could make the unfortunate decision over evaluating ones' decision-making abilities.

Therefore, the area of freedom in the organization is also dependent on the dimensions of the organization status. The first dimension of the organizational structure is the level of centralization. Low centralization means greater freedom in making decisions at lower levels in the organization.

The second dimension of the organizational structure is the formalization that describes the tasks, powers and responsibilities of individual employees. If there is a high formalization, everything is exactly described and there is not much freedom. Formalization also applies to the number of documents in the organization related to the execution of specific activities. Their number also has a negative effect on the level of freedom.

The third dimension of the organizational structure is specialization. Low specialization is associated with a wide range of activities that employees can perform in the process, which increases the level of freedom. High specialization occurs when an employee performs a narrow range of activities in the process. Then there is no place for freedom.

The fourth dimension is standardization, which is related to the unification of standards (e.g. how to perform specific tasks). High standardization allows you to produce products of the same quality. However, too high standardization reduces the organization's flexibility. Organizations are not quickly 
able to react to changes in the environment. What's more, the initiative is also disappearing in search of new solutions, so the level of freedom also decreases.

Ivancevich and Matteson (1996) state, "power represents the capability to get someone to do something; influence is the exercise of that capability". From this statement, it is clear that in order to exercise this power and influence, freedom is necessary. The manager cannot influence his subordinate if his time is spent ensuring he follows a theoretical (or realistic) rule-book in order to keep with certain practices deemed paramount (Organa, 2018). Power must be followed by responsibility and being thrust into such a position means that those who put him there must trust the manager to do his job, which allows one to infer that freedom is a given in such situation.

Managing implies that others are planning goals, and it is his job to achieve those goals. The ones inventing these goals must also invent strategies in order to achieve them. The job of the manager is to solve problems and achieve goals, not to create and discover new goals. As previously stated, certain occupations will require a more systematic, or scientific approach to management. Melé and Rosanans (2013) state in their article that [Frederick W.] Taylor's conception of an organisation and the human beings working in it was rather simplistic: the efficiency of blue-collar workers was rather low and could be improved by thinking about it scientifically. The manager cannot be allowed to do as he might sincerely wish like a dog let off the leash. Protocols must be followed, regulations obeyed, and efficiency maximised, for he is still a subordinate to someone that holds authority over his position; whether that be owners, executives, or even the consumer. The manager plays a role in a larger picture at all times (Chmielewska-Muciek \& Sitko-Lutek, 2013). It is easy for a manager to get tunnel-vision, and following protocols can help to prevent failures arising from this. Those protocols were not thought up out of anywhere, or on a whim. They were put together by experts who have learned from previous mistakes in order to ensure that they do not recur (Solari, 2016).

Just as it is essential for the manager not to become narrow-minded, and succumb to tunnel-vision, so it is for a manager to maintain at least a moderate amount of freedom in order to adapt. That ultimately is the reason that a manager must be allowed the freedom to do his job: to adapt to changing circumstances. The inability to adapt is a dangerous beginning that ultimately leads to failure (Howell et al., 1990). The manager and his senior must dramatically balance the pendulum of autonomy in order to achieve their goals. Just as general G. S. Patton once state, "Do not tell people how to do things, tell them what to do and let them surprise you with their results" (Grumet, 2010). The manager must also receive orders from his senior, and his job is to interpret those orders to his subordinates. This is an impossibility if managerial freedom does not exist, and in that case, there might as well be no manager.

\section{Examples of Organisations}

The economic development needs freedom in order of making independent choices, bearing personal responsibility, open to changes, unexpected situations (Chmielewska-Muciek, 2018). When it comes to the general advantages of the implementation of freedom into the organisation, workers that feel more freedom tend to be more loyal towards their employer (Pawłowska, 2007). G. Broniewska states that there is a positive correlation between the quality of a worker's life and their freedom (Broniewska, 2005). Along with that, J. Lipowska describes that the tolerance of freedom in the organisation acts as one of the components of managerial practices that builds employee's creativity (Lipowska, 2013). Besides, K. Beyer lists freedom as one of the conditions for the knowledge-based organisation (Beyer, 2012). 
One of the best examples of the usage of one of the principles of freedom management is the Apple which found the uniqueness of different market's unexploited potential that they subsequently used to dominate across the world. Their key was to look for the underserved sectors which were ignored and not considered relevant by the rest of the market participants. Such an approach has led the company to success and eventually paid off. Blue Ocean strategy is also the thing that was used by Apple in that case - in this strategy companies have to identify their uniqueness compared to their competitors and take advantage of it to explore the profound and full potential of the market (Kim \& Mauborgne, 2004).

To give an illustration of creative entrepreneurship, the examples of HP, Nucor Steel, Southwest Airlines, and Wal-Mart can be given - their employees' successful entrepreneurship helped the companies to outperform one of the most extensive indexes S\&P500 for three decades (Nobless \& Staley, 2009).

However, not all the companies coped with the changing management and organisational realities, and the story of Nokia is a part of them. The company was not able to open-mindedly look on the new market sentiments and preferences like cutting-edge touch screens introduced by Apple and Samsung, and as a result of a failed strategy, Nokia was hence acquired by Microsoft. Shell is the other firm that could not incorporate changes in the external environment into its' structure. The firm was involved in the longlasting battle over its' reputation due to the fact they were involved in support of military operations against the Ogoni ethnic group in Nigeria. The case was treated as a massive act of human rights violation (Summers, 2017).

Freedom penetration into the organisations might become a solution on how to restore the reputation of capitalism and free market exposure that was severely deteriorated by the corruption in management (Nobless \& Staley, 2009). According to Bill Nobles and Paul Staley, honesty, freedom dispersing power, open access to information and profound motivation can create an army of internal auditors behaving for the good of the organisation and combating the issues.

On the other hand, it can be quite hard to define which freedom exactly will lead a particular company to success. Innovative leaders tend to operate intuitively, and no-one identified the freedom theme common to their successes - the freedom that offers a compelling alternative for hierarchical control (Nobless \& Staley, 2009). There are companies that are characterized by a low level of freedom and are also successful (e.g. McDonald's). All their restaurants look the same. What's more, the food is the same all over the world (high standardization). In addition, the owners of franchise premises are not able to make key decisions (high centralization). All products are prepared at the same workplace, according to the same procedures, which are strictly described in documents (high formalization). This is an example of an organization that fits into scientific management (each element of work is thoroughly researched and described). What's more, employees are only cogs in the machine and perform a narrow set of activities in the process (high specialization) However, lack of freedom in management was not a barrier to achieving global success.

There is also a controversial view given by Alexander Shadrin (2005) in the article "The problem of freedom in the theory and practice of organisation management", where he claims that the dominance of the freedom paradigm leads to fundamental flaws in modern theory and practice of management. According to him, it can be overcome with the help of all the best that is concentrated in the already known management standards. Alexander highlights the following problems of freedom in management (Chmielewska-Muciek \& Sitko-Lutek, 2013):

1. the concept of "freedom" is rooted in the minds of people as an absolute value; however, the absence of restrictions in management is not acceptable for either the individual or the organisation; 
2. at all times, freedom is understood by different people in different ways, and in this situation, the desire for freedom often leads to severe conflicts;

3. in management practice, the stable success of an organisation is possible only in case of compliance with common management rules, reflected in management standards (Shadrin, 2005).

\section{Conclusion}

There is a strong tendency among modern companies to implement some freedom-based management practices; however, in some cases, it is not done fully conscious. This type of management has its pros and cons that are applied to each organisation differently and should be analysed case by case. Most of the researches stick to the opinion that freedom in management creates new opportunities and helps in the development and evolution of the firms. On the contrary, there is another side to that opinion that believes that at this moment freedom in management is not deemed to be prosperous due to the complexity of the notion and people's nature. To sum up, the efficiency, relevance and need for freedom in management has to be scrutinised from the perspective of separate organisations and cannot be generalised.

\section{Acknowledgement}

The project is financed by the Ministry of Science and Higher Education in Poland under the programme "Regional Initiative of Excellence" 2019 - 2022 project number 015/RID/2018/19 total funding amount 10721 040,00 PLN.

\section{References}

Beyer, K. (2012). Współczesna organizacja - organizacja oparta na wiedzy. Zeszyty Naukowe Uniwersytetu Szczecińskiego, 736, 9-25.

Bogusz, K., \& Ziemkiewicz, J. (2018). Zrównoważony rozwój przedsiębiorstw z branży surowcowej na przykładzie KGHM Miedź SA”, in Kulczycka, J. (Ed.), Elementy Zarządzania w Zrównoważonym Rozwoju i Gospodarce o Obiegu Zamknietym, Instytut Gospodarki Surowcami Mineralnymi i Energią Polskiej Akademii Nauk, Kraków, pp. 7-20.

Broniewska, G. (2005). Jakość życia człowieka w organizacji w świetle filozofii TQM. Problemy Jakośc, 5, 27-30.

Chmielewska-Muciek, D. (2018). Wolność w polskich organizacjach. Studia Ekonomiczne. Zeszyty Naukowe Uniwersytetu Ekonomicznego w Katowicach, 349, 17-25.

Chmielewska-Muciek, D., \& Sitko-Lutek, A. (2013). Organizational Culture Conditions of Knowledge. International Conference of Knowledge Management \& Innovation.

Dierksmeier, C. (2011). The Freedom-Responsibility Nexus in Management Philosophy and Business Ethics. Journal of Business Ethics. Retrieved from https://doi.org/10.1007/s10551-010-07219.

Dierksmeier, C., \& Pirson, M. (2010). The Modern Corporation and the Idea of Freedom. Philosophy of Management, 9(3), 5-25.

Gomme, G.L. (1874). “Adam Smith”, Notes and Queries. Retrieved from https://doi.org/10.1093/nq/s5I.9.168-c.

Grumet, G.W. (2010). General George S. Patton, Jr. and the Conquest of Fear. Psychological Reports, Retrieved from https://doi.org/10.2466/pr0.105.1.314-338.

Howell, J.P., Bowen, D.E., Dorfman, P.W., Kerr, S., \& Podsakoff, P.M. (1990). Substitutes for leadership: Effective alternatives to ineffective leadership. Organizational Dynamics. Retrieved from https://doi.org/10.1016/0090-2616(90)90046-R. 
Ivancevich, J., \& Matteson, M. (1996). Organizational behavior and management. 4th ed., Richard D. Irwin, Chicago.

Karaferye, F., \& Agaoglu, E. (2017). Perceptions of the Dilemma--Order versus Freedom at Managing Faculty: A Literature Review. Journal of Education and Practice.

Khall Khalid, S. (2019). Create Shared Value, as a New Competitive Advantage, and its Impact on Sustainable Strategy Analytical Study Applied on a Sample of Hotels in Erbil City.

Proceedings Book of International Conference on Accounting, Business, Economics and Politics, ICABEP 2019, Tishk International University in Erbil, Erbil, Kurdistan Region of Iraq, pp. 402-413.

Kim, W.C., \& Mauborgne, R. (2004). Blue ocean strategy. Harvard Business Review.

Lipowska, J. (2013). Zależnosć kreatywności pracowników od elementów środowiska pracy. Zarządzanie Zasobami Ludzkimi, 1.

Melé, D., \& Rosanans, J.M. (2013). Power, Freedom and Authority in Management. Philosophy of Management, 3(2), 35-46.

Nobless, B., \& Staley, P. (2009). Freedom-Based Management. Retrieved from http://www.42projects.org/docs/FreedomBasedManagement.pdf.

Organa, M. (2018). Leadership embedded within centralized and decentralized networks: A case study of IT software and services company. Proceedings of the 31st International Business Information Management Association Conference, IBIMA 2018: Innovation Management and Education Excellence through Vision 2020, pp. 4260-4272.

Pawłowska, B. (2007). Kultura organizacji a proces instytucjonalizacji sposobu motywowania pracowników, in Konecki, K.T. and Chomczyński, P. (Eds.), Arządzanie Organizacjami. Organizacja Jako Proces, Wydawnictwo Uniwersytetu Łódzkiego, Łódź.

Shadrin, A. (2005). The problem of freedom in the theory and practice of organization management. Problems of Theory and Practice of Management, 8.

Smith, A. (2011). Wealth of Nations. The Two Narratives of Political Economy. Retrieved from https://doi.org/10.1002/9781118011690.ch9.

Solari, L. (2016). Freedom Management: How leaders can stay afloat in the sea of social connections.

Sulich, A., \& Zema, T. (2017a). Oczekiwania płacowe i pozapłacowe studentów oraz absolwentów Politechniki Wrocławskiej wobec pierwszego pracodawcy w 2015 roku, in Woźniak, M., Drewniak, M. and Tańska, H. (Eds.), Nauka i Biznes - Wyzwania XXI Wieku. Cz. 3, Wydawnictwo Naukowe Intellect, Waleń"czów, pp. 38-48.

Sulich, A., \& Zema, T. (2017b). Problem zarządzania ryzykiem we współczesnej filozofii techniki”, in Olkiewicz, M., Woźniak, M., Drewniak, M. and Chmura, J. (Eds.), Nauka i Biznes - Wyzwania XXI Wieku. Cz. 2, Wydawnictwo Naukowe Intellect, Waleńczów, pp. 8-21.

Summers, H. (2017). Amnesty seeks criminal inquiry into Shell over alleged complicity in murder and torture in Nigeria, The Guardian. Retrieved from https://www.theguardian.com/globaldevelopment/2017/nov/28/amnesty-seeks-criminal-inquiry-into-shell-over-alleged-complicityin-murder-and-torture-in-nigeria.

Tikhonova, E., \& Zaytseva, O. (2015). The middle management freedom in a modern organisation. Moscow University Bulletin, 4, 266.

* This paper was presented at ICABEP 2019 (International Conference on Accounting, Business, Economics and Politics) Conference in Erbil, Iraq. 